\title{
Treaty Interpretation or Activism? Comment on the AB Report on United States - ADs and CVDs on Certain Products from China
}

\author{
JOOST PAUWELYN* \\ Graduate Institute, Geneva
}

This comment is limited to the 'public body' issue and the question of so-called 'double remedies'. It ends with a few tentative explanations as to why the Appellate Body in this dispute opted for a rather restrictive interpretation or, depending on one's viewpoint, activist approach as compared to the Panel in the same case.

\section{Public body}

On 'public body', Prusa and Vermulst write that the Appellate Body's (AB) 'conclusions and analysis were correct' (see abstract), unfortunately, without further explanation. Unless tweaked in future refinements, the AB's test of 'governmental authority/function' is highly questionable as a matter of law, and unlikely to work as a matter of practice.

The applicable SCM provision refers to 'a financial contribution by a government or any public body within the territory of a Member' (underlining added). By defining 'public body' as limited to entities that are exercising 'governmental authority', the AB has essentially read out of the SCM Agreement the words 'or any public body'. If the drafters only wanted to cover what is usually understood as 'government', they would not have added these words. When the AB refers to the Articles on State Responsibility of the International Law Commission (ILC) on the subject of when (wrongful) conduct can be 'attributed' to a 'state', the ILC defines what is meant by 'government' or 'state'. Yet, the SCM Agreement went beyond this and expanded coverage to include not only 'government' but also 'any public body'. The ILC Articles say nothing on the meaning of 'public bodies',

\footnotetext{
* For the benefit of full disclosure, the author has been involved in this dispute on the side of certain US companies who originally petitioned US authorities to impose AD and CVD duties against selected imports from China. The opinions expressed in this comment are, however, strictly personal and cannot be attributed to anyone else but the author himself.
} 
a term that does not even appear in those Articles. The AB relies ultimately on ILC Article 5. Yet, the reasoning is circular: The only thing that Article 5 says is that 'conduct of a person or entity ... which is empowered by the law of that State to exercise elements of the governmental authority' shall be considered 'an act of the State'. So all that Article 5 says is the obvious and was not contested, namely that entities 'exercising elements of governmental authority' are, indeed, part of the 'government'. It says nothing on what a 'public body' is, let alone does it limit the definition of 'public body' to the entities covered under Article 5. Again, Article 5 and the entire ILC Articles do not even mention the words 'public body'.

A better approach would have been (i) to consider the SCM Agreement as lex specialis (after all, SCM Article 1 sets out primary rules on what is a subsidy - ILC Articles 4-8 elaborate on secondary rules in respect of attribution of wrongful conduct); (ii) to examine the ordinary/dictionary meaning of 'public body' which, the $\mathrm{AB}$ conceded, includes bodies controlled by the state; and (iii) to then assess whether anything in the surrounding context of the SCM Agreement should lead the $\mathrm{AB}$ to exclude from this 'ordinary meaning' entities controlled by the government. No such excluding language exists: not in the SCM Agreement or anywhere else in the WTO treaty or in the ILC Articles. If anything, when it comes to China, China's Working Party Report confirmed that state-owned enterprises are 'government actors' for purposes of SCM Article 1.1(a). ${ }^{1}$

Instead, we are now left with what could turn out to be a very unclear and subjective test of 'governmental authority/function': When does an entity have governmental authority? What is a governmental function? How can any of this be proven? Will governments not find ways to hide delegation of power or instructions, especially if they control the board of a company anyhow? An informal phone call or discussion should suffice, without leaving any trace, so how is a competitor supposed to find evidence of this - as the Panel in this dispute put it, this would amount to finding 'evidence that the government directed itself'.

The test of 'control' by the government (e.g. through ownership or the right to appoint directors), that is, the test upheld by the Panel in this dispute (and previous Panels before it) is a more objective test and more workable, even though it does remain a proxy. After all, at this stage ('financial contribution by a government or any public body'), the question is only about who gives the financial contribution, what is the nature of the body or entity providing the loan or goods, not why the loan or goods are provided (e.g. for this or that governmental or other purpose).

1 Paragraph 172 of China's Working Party Report, confirmed as a binding part of China's accession through China's Accession Protocol, provides: 'Some members of the Working Party, in view of the special characteristics of China's economy, sought to clarify that when state-owned enterprises (including banks) provided financial contributions, they were doing so as government actors within the scope of Article 1.1(a) of the SCM Agreement. The representative of China noted, however, that such financial contributions would not necessarily give rise to a benefit... The Working Party took note of this commitment' (underlining added). 
The question of what is done or why, comes up only later, under 'benefit'. For example, a loan is provided by the government or a public body, which in itself is not a problem or wrongful. It becomes a problem or 'subsidy' only if the loan is provided below market terms, that is, so as to 'benefit' the one receiving the loan and is specific. This noncommercial nature of the loan is then seen as a proxy for the loan being awarded for noncommercial purposes, if you wish, in pursuit of one or the other 'governmental function'. As Cartland et al. put it: 'the question of whether a particular entity can be considered a public body... has simply to do with whether the entity can be used as a conduit for providing a subsidy ... being vested with or exercising [governmental] authority is unnecessary for an entity to be a conduit for subsidies. ${ }^{2}$

The best way out of this conundrum may already be indicated by the AB itself, when it found that proof of 'meaningful control' by the government can be sufficient evidence of exercise of governmental authority. ${ }^{3}$ Ultimately, the $\mathrm{AB}$ already found that Chinese state-owned commercial banks are 'public bodies', even under its newly announced test of 'governmental authority/function', and this on relatively little, additional evidence of these banks operating under the influence of, and in pursuit of, governmental objectives. If further tweaked in this direction, the test may be clarified and become more workable, by essentially moving back to evidence of 'meaningful control' by the government (not just majority ownership) which can then work as a proxy of governmental authority/function (unless rebutted by the government in question who will, in most cases, be the only party in possession of the relevant evidence anyhow).

\section{Double remedies}

In respect of 'double remedies', Prusa and Vermulst offer an insightful analysis of the economics of cumulative application of countervailing (CVD) and antidumping (AD) duties. They show that in many, if not most, scenarios (export subsidies, domestic subsidies in nonmarket economies as well as domestic subsidies in market economies) some overlap or 'double remedy' is possible, depending on a number of factors, in particular, the degree of pass-through of the subsidy on domestic prices, export prices, and/or surrogate values in a third country. Overlap is, in other words, a matter of degree and calculation. However, what they overlook is that the drafters of the WTO treaty were aware of this and to simplify matters set up a number of 'legal fictions'. In GATT Article VI:5, they did outlaw cumulative application of CVD and AD duties in respect of export subsidies, based on the

2 M. Cartland, G. Depayre, and J. Woznowski (2012), 'Is Something Going Wrong in the WTO Dispute Settlement?', 46:5 Journal of World Trade, 979, at 1000 and 1001.

$3 \mathrm{AB}$ Report, para. 318: 'evidence that a government exercises meaningful control over an entity and its conduct may serve, in certain circumstances, as evidence that the relevant entity possesses governmental authority and exercises such authority in the performance of governmental functions'. 
simplifying assumptions or 'legal fiction' that an export subsidy will have no impact on domestic prices and fully pass through into lower export prices. ${ }^{4}$ The drafters of GATT (in 1947) and later the SCM Agreement (in 1994) and, later still, China's Accession Protocol (in 2001) did not impose a similar prohibition in respect of other (domestic) subsidies. They could have done so, and based on GATT Article VI:5 knew how to do this, but did not do so. Instead, for domestic subsidies they 'assumed' something different and, to simplify complex economic effects, worked on the basis of another 'legal fiction', namely that domestic subsidies pass through to the same extent into both domestic and export prices so that a prohibition on cumulation is not warranted. For domestic subsidies in a nonmarket economy (NME), such as (in US eyes) China, where surrogate values in a third country may be used, this 'legal fiction' may be more tenuous than in a market-economy scenario (although, as Prusa and Vermulst admit, also surrogate values may be affected by subsidies). Yet the drafters maintained the fiction also for nonmarket economies. Indeed, in Rule 15 of China's Protocol of Accession they elaborated in quite some detail how $\mathrm{AD}$ and CVD can be imposed against Chinese imports without, at any stage, even hinting at the fact that, when it comes to China as an NME, a choice must be made between either AD or CVD.

Many of these 'legal fictions' may be inaccurate from an economic perspective as they may not capture the exact economic effects in all scenarios. Yet, for negotiators, lawyers, and investigators, these 'legal fictions' were considered necessary to simplify matters. That these 'fictions', and the legal rules that are built on them, make limited economic sense is no reason to change the rules or to make a finding of violation. Yet, that is exactly what Prusa and Vermulst call for. That 'the economic rationale for banning simultaneous $\mathrm{AD}$ and $\mathrm{CVD}$ for export subsidies applies equally well (or perhaps even better) to domestic subsidies when the NME method is used to compute normal value' may well be correct. Yet, this is no excuse for the $A B$, as an adjudicator (not a legislator), to change the explicit text of the one rule where cumulation is prohibited, that is, to amend GATT Art. VI:5 for it to outlaw not only cumulation in respect of export subsidies but also in respect of (some) domestic subsidies. Many WTO rules do not make full economic sense. Applying the same logic, GATT Art. XI:1, which only prohibits quantitative export restrictions (not export taxes), would then also need to be 'judicially revised' as, in economic terms, one can achieve the same effect with a (permitted) export tax as the effect stemming from a (prohibited) export quota. There as well, in Prusa and Vermulst's words, 'the economic rationale for banning [quantitative export restrictions] applies equally well to [export taxes]'.

4 GATT Article VI:5 reads as follows: 'No product of the territory of any contracting party imported into the territory of any other contracting party shall be subject to both anti-dumping and countervailing duties to compensate for the same situation of dumping or export subsidization.' 
Prusa and Vermulst use the analogous economic rationale for export subsidies and the cumulation of CVD and AD duties in an NME scenario to conclude that, in the latter scenario as well, the $\mathrm{AB}$ should simply have prohibited any cumulation (as GATT Art. VI:5 does in respect of export subsidies) rather than calling upon US investigating authorities to measure the actual extent of overlap and to then limit CVD duties accordingly. Since 'measurement [of double remedies] is extremely messy and complicated', Prusa and Vermulst suggest to impose the same simplifying 'legal fiction' as the fiction imposed for export subsidies in GATT Art. VI:5 and to outrightly prohibit any cumulation of CVD and AD duties in an NME scenario. Measuring the exact degree of cumulation will, indeed, be messy. However, WTO drafters realized this and, as pointed out earlier, did opt for a number of simplifying 'legal fictions': for export subsidies they prohibited cumulation; for other subsidies they did not. Prusa and Vermulst may be correct that one better turns to a 'legal fiction' instead of opening Pandora's box of trying to measure the exact degree of pass-through and resulting overlap. However, the legal fiction they then turn to is not the one currently written in the WTO rule book, but the legal fiction they would opt for if they had to redraft the WTO treaty. This is not the role of an adjudicator, but the task normally bestowed on treaty negotiators.

Prusa and Vermulst do not even address the ultimate legal hook on which the $\mathrm{AB}$ hung its prohibition on double remedies in the NME scenario, namely SCM Article 19:3. It seems beyond doubt that the drafters of this provision did not even think of this scenario, let alone the prohibition that the AB read into Article 19:3. ${ }^{5}$ Article 19:3, in relevant parts, simply reads that 'when a countervailing duty is imposed ... such countervailing duty shall be levied, in the appropriate amounts in each case, on a non-discriminatory basis on imports of such products from all sources found to be subsidized'. By its very terms, this provision addresses not the calculation of a subsidy or a CVD duty, nor the imposition of a CVD, but only the subsequent and technical step of actually 'levying' the CVD duty set in earlier steps. Moreover, it has nothing to do with adjusting the CVD duty in view of certain circumstances (e.g. cumulation with an AD duty) but only with ensuring that the correct or 'appropriate' CVD duty is imposed on the relevant product, on a 'non-discriminatory basis' (e.g. if one Chinese producer got subsidies of 10 per unit, and another subsidies of only 5, the CVD levied on imports of the first should, appropriately, be 10 and those of the second 5). Finally, Article 19:3 explicitly lists those scenarios where a CVD can no longer be imposed (renunciation of the subsidy or where an undertaking has been accepted), and this list does not include nor even remotely refer to the question of $\mathrm{AD}$ or cumulation.

5 Cartland et al., supra note 2, at 995 ('The effect of the AB's analysis ... is to render the lesser-duty rule essentially mandatory in the context of simultaneous application of $\mathrm{AD}$ and $\mathrm{CVD}$ to non-market economies ... One does not to be a researcher in the history of the negotiations of Article 19 ... to know that such a linkage between the amount of a subsidy and injury has never been agreed.'). 


\section{Treaty interpretation or activism?}

In conclusion, both in respect of 'public body' and 'double remedies', the AB has opted for an approach that limits the scope for investigating authorities to impose countervailing duties: a financial contribution can only amount to a 'subsidy' when provided by an entity exercising governmental authority; the amount of a CVD, in the NME scenario where also AD duties are imposed, must be adjusted and limited to avoid 'double remedies'. It is notoriously difficult to decide whether this is an instance of AB activism (reading 'any public body' out of the SCM Agreement and reading a prohibition on cumulation into Art. 19:3 where the drafters provided none) or whether this is merely an instance where the $\mathrm{AB}$ interpreted the WTO treaty restrictively following the steps of treaty interpretation set out in the Vienna Convention on the Law of Treaties. This is a matter that, more often than not, lies in the eye of the beholder.

What can, in any event, be said is that compared to the Panel in this case (who interpreted public body as including entities controlled by the government, and did not see a prohibition on cumulative application of $\mathrm{AD}$ and CVD duties other than in the scenario of export subsidies), the $\mathrm{AB}$ has taken a considerably more restrictive approach. What could possibly explain this rather drastic move, and dramatic reversal of the Panel Report? Is this proof of the $A B$ slowly removing itself from a predominantly textual approach to treaty interpretation? Did the $\mathrm{AB}$ decide these matters as questions of first impression, inspired by elements of common sense, general principles, or analogies more than the actual rules agreed upon? In the face of deadlock in the Doha Round of negotiations for more than ten years now, is the AB hereby more willing to update the rules itself to newly emerging circumstances, even though the original drafters most probably never thought of these new scenarios?

One puzzling element, in this respect, is the AB's almost complete neglect of China's Accession Protocol (in particular Rule 15 on AD and CVD) as well as China's Working Party Report (quoted earlier). These documents postdate the conclusion of the WTO treaty and provide a more updated expression of intent, one that is, in addition, focused on the peculiar situation of China. They could and did provide additional insights into what WTO negotiators had in mind. Yet, partly because of how the parties argued the case, the $A B$ did not seek to benefit from them and instead opted for a more inward looking, judicial approach.

Writing in 2004, Richard Steinberg was not all that worried about the imbalance between the (automatic) judicial branch and the (consensus-blocked) legislative branch of the WTO, pointing out correctly that there are multiple, informal ways in which WTO members (as principals) can steer or influence Panels and the AB (as agents). ${ }^{6}$ Yet, principal-agent literature teaches us that the existence of multiple

6 Richard H. Steinberg (2004), 'Judicial Lawmaking at the WTO: Discursive, Constitutional, and Political Constraints', 98:2 American Journal of International Law, 247-275. 
principals affects overall discretion of the agents (or interpretation space in our case). ${ }^{7}$ If divergence of interests among principals increases, new autonomy will open up for judicial agents or, as John Ferejohn put it, 'Courts and agencies are capable of independent or autonomous action where the constitutional legislature is too fragmented to react.'8 This is a crucial insight which may explain the AB's restrictive interpretation or, if you wish, activism, in this and some other more recently decided disputes. ${ }^{9}$ Whereas at the time of its creation in 1994, the WTO was controlled by a handful of countries (especially the EU and the US), in more recent years multiple powerful actors have emerged (including China, Brazil, India, and South Africa and, most recently, Russia). This interest divergence increases the $A B$ 's interpretation space, and, in turn, enables the $\mathrm{AB}$ to be more activist, knowing that its rulings may upset some powerful countries but please others. Steinberg pointed out, in 2004, that 'WTO dispute settlement could assume a new form as a result of fundamental changes in the political environment, such as the dispersion of power at the WTO or a divergence of interests of powerful states. If either shift were to occur, the strategic space for judicial lawmaking at the WTO would expand, as it would become more difficult to establish and sustain the political cooperation necessary to check or correct AB action.' ${ }^{10}$ The 2011 AB Report on US-China ADs and CVDs may well be evidence of a move in exactly this direction.

7 Daniel L. Nielson, and Michael J. Tierney (2003), 'Delegation to International Organizations: Agency Theory and World Bank Environmental Reform', 57:2 International Organization, 241-276.

8 John Ferejohn (2002), 'Judicializing Politics, Politicizing Law', 65:3 Law and Contemporary Problems, 41-68 at p. 63.

9 See Manfred Elsig and Joost Pauwelyn (forthcoming 2013), 'The Politics of Treaty Interpretation: Variations and Explanations Across International Tribunals', in Jeffrey L. Dunoff and Mark A. Pollack (eds.), Interdisciplinary Perspectives on International Law and International Relations: The State of the Art, Cambridge: Cambridge University Press.

10 Richard H. Steinberg (2004), 'Judicial Lawmaking at the WTO: Discursive, Constitutional, and Political Constraints', 98:2 American Journal of International Law, 247-275, at p. 275. 